\title{
ANALISIS PIUTANG TAK TERTAGIH BERDASARKAN UMUR PIUTANG PADA PERUSAHAAN MANUFAKTUR
}

\author{
Oleh: \\ Chairani \\ Dr.Meifida Ilyas, SE.,M.Si.,AK.,CA.,CSRS \\ Program Studi Fakultas Ekonomi Universitas Satya Negara Indonesia
}

\begin{abstract}
ABSTRAK
Di beberapa perusahaan, aktivitas penjualan baik tunai atau kredit merupakan kegiatan yang penting untuk mencapai tujuan utama yaitu untuk memperoleh laba yang optimal. Terutama perusahaan manufaktur. di beberapa perusahaan manufaktur untuk mengelola keuntungan perputaran menjadi penjualan secara kredit. Dalam penjualan kredit ada dua sisi yang satu adalah memberikan kredit dan lain menerima kredit. Ini menyebabkan piutang bagi kreditur dan juga akun hutang untuk debitur. Jadi sebenarnya dari kemampuan penjualan kredit akan membuat klaim terhadap akun piutang kepada kreditur. Walaupun piutang tidak dapat dibayar atau klien menjadi bangkrut, itu disebabkan beban piutang ragu ragu atau piutang tidak tertagih. Ini disebabkan dalam transaksi kredit ada lebih banyak waktu sebelum debitur membayar rekening hutang, dalam kondisi ini kemungkinan piutang tidak tertagih masih akan terjadi.

Objek penelitian ini adalah beberapa perusahaan manufaktur. Tujuan dari penelitian ini adalah untuk mengetahui perpanjangan umur piutang, persentase tidak tertagihnya piutang atau beban piutang tak tertagih. Metodologi yang digunakan dalam penelitian ini adalah metode deskriptif statistik. Yang merupakan statistik yang menjelaskan bagaimana cara untuk mengumpulkan data, untuk membangun data, mempersiapkan dan menganalisa jumlah data. Dalam rangka memberikan penjelasan singkat dan jelas tentang kondisi perusahaan, sehingga dapat membuat kesimpulan.

Hasil penelitian menunjukkan bahwa, lebih panjang umur piutang sehingga lebih tinggi persentase beban piutang tak tertagih. Hal tersebut dapat dilihat dari perhitungan hasil rata-rata persentase piutang tidak tertagih berdasarkan umur piutang, yang rata-rata tidak tertagih piutang 9,16\% untuk 1-30 hari, rata-rata 31-60 hari adalah 13,66\%, ratarata $61-90$ hari adalah $25,66 \%$, selanjutnya rata-rata $91-180$ hari adalah $34,83 \%$, dan kemudian rata-rata 181-365 hari adalah $45,33 \%$, dan yang terakhir lebih satu tahun ratarata piutang tidak tertagih adalah $67,16 \%$.
\end{abstract}

Kata kunci: Beban Piutang ragu-ragu (piutang tidak tertagih), umur piutang, piutang perusahaan Manufaktur 


\section{PENDAHULUAN}

\section{Latar Belakang Penelitian}

Pada sebuah perusahaan khususnya perusahaan manufaktur, manajemen keuangan memiliki peran yang cukup penting dalam sebuah fungsi manajemen perusahaan. Pada saat perusahaan melakukan sistem penjualannya secara kredit maka kemudian akan timbul piutang. Hal ini akan berpengaruh pada laporan keuangan perusahaan terutama berdampak pada arus kas. Adapun suatu masalah yang sering terjadi yaitu saat konsumen lalai dalam melakukan pembayaran. Hal ini akan berdampak bagi perusahaan, yaitu keterlambatan dalam pelunasan piutang dan arus kas perusahaan pun akan menurun sehingga berpengaruh pada efektivitas kegiatan operasional perusahaan.

Penjualan kredit melibatkan dua pihak yaitu pihak yang memberi kredit dan pihak yang menerima kredit, dimana akan timbul piutang bagi pihak kreditur dan hutang bagi pihak debitur. Akibat dari kebijakan penjualan secara kredit akan menimbulkan hak penagihan piutang.

Penagihan Piutang merupakan aktivitas yang sangat mempengaruhi jumlah pendapatan dari perusahaan setiap akhir periodenya. Salah satu cara yang dilakukan untuk memperkecil resiko piutang tak tertagih, maka tiap bulan perusahaan akan mengeluarkan dan mengirimkan laporan bulanan kepada tiap pelanggan tentang saldo piutang yang belum dilunasi yang dirinci menurut umurnya.

Piutang usaha yang muncul, apabila tidak dapat dibayarkan atau terjadi kemungkinan klien bangkrut atau menghilang, maka akan mengakibatkan munculnya piutang tak tertagih. Hal ini disebabkan karena dalam transaksi kredit ini ada tenggang waktu sebelum pelunasan hutang dari pihak debitur dan kondisi ini komponen piutang tak tertagih kemungkinan besar masih bisa terjadi. Untuk mengatasi hal ini maka diperlukan pengawasan yang ketat oleh manajemen perusahaan terhadap pengendalian piutang untuk menghindari kerugian yang cukup besar. Tidak ada satu pun dari perusahaan yang mengharapkan bahwa dari sekian banyaknya debitur terdapat sebagian yang tidak bisa membayar kewajibannya walaupun dalam proses pemberian kredit telah di teliti sebaikbaiknya. Namun, pada kenyataannya resiko tak tertagih atas sejumlah piutang pasti akan ditemui. Untuk itu perusahaan seringkali membuat daftar piutang berdasarkan umurnya (aging schedule) untuk memudahkan perhitungan piutang yang beredar kemudian menghitung cadangan kerugian piutang yang akan dibebankan pada akhir periode untuk mengakomodasikan kemungkinan piutang tak tertagih. Piutang tak tertagih ini biasanya oleh pihak perusahaan menetapkan persentase tertentu untuk menggambarkan seberapa besar pengaruhnya terhadap kondisi keuangan perusahaan. Biasanya pengenaan persentasenya ditentukan berdasarkan umur piutang tersebut dan berdasarkan pengalaman periode yang lalu. Oleh karena itu, Pencatatan piutang merupakan hal yang harus diperhatikan oleh perusahaan-perusahaan yang mengadakan penjualan secara kredit. Hal tersebut dikarenakan piutang merupakan salah satu unsur aktiva lancar yang nilainya relatif besar dan mempunyai resiko yang tinggi sehingga apabila tidak dicatat dengan baik, manejemen akan mengalami kesulitan dalam mengambil keputusan sehingga dapat mengakibatkan kerugian atas penjualan secara kredit kepada pelanggan. Selain itu, dalam pelaksanaan penjualan pimpinan perusahaan harus benar-benar memperhatikan hal-hal yang dapat menimbulkan terjadinya piutang tak tertagih, karena hasil dari penjualan ini akan menentukan kelangsungan hidup dari perusahaan dalam arti kemampuan perusahaan untuk memperoleh laba yang memadai dalam jangka panjang. . Hal-hal yang menentukan kelangsungan hidup perusahaan diantaranya adalah untuk 
mengurangi resiko piutang tak tertagih yang harus ditanggung perusahaan, perusahaan perlu melakukan pemeriksaan secara teratur terhadap kebijaksanaan perusahaan secara keseluruhan, khususnya dengan memperhatikan pengumpulan piutangnya setiap hari, bulan, dan periode terhadap penjualan kredit.

Pada beberapa perusahaan manufaktur yang tersebar di Jakarta khususnya yang melakukan penjualan secara kredit, masih terdapat piutang usaha yang perlu di analisa, berapa persentase piutang tak tertagih dan berapa lama umur piutang pada masing-masing perusahaan manufaktur tersebut, sehingga dapat menjadi acuan bagi masing-masing perusahaan untuk menstabilkan piutang yang kemungkinan tak mungkin tertagih. Berdasarkan uraian latar belakang diatas maka penulis tertarik untuk melakukan penelitian dengan judul: "Analisis Piutang Tak Tertagih berdasarkan Umur Piutang pada Perusahaan Manufaktur".

\section{Perumusan Masalah}

Apakah semakin lama umur piutang, semakin besar persentase piutang tak tertagih yang ditetapkan pada perusahaan manufaktur?

\section{LANDASAN TEORI}

\section{Konsep Akuntansi}

Akuntansi sering disebut sebagai bahasa bisnis atau bahasa dari keputusan keuangan. Hal ini disebabkan oleh karena banyak aspek sehari-hari yang didasarkan pada akuntansi seperti perencanaan keuangan pribadi, biaya pendidikan, investasi pinjaman, pajak penghasilan dan banyak aspek lainnya.

Definisi akuntansi menurut Soemarso (2004 : 3) mengutip pernyataan American Accounting Association (AAA), yaitu akuntansi sebagai proses mengindentifikasikan, mengukur dan melaporkan informasi ekonomi, untuk memungkinkan adanya penilaian dan keputusan yang jelas dan tegas bagi mereka yang menggunakan informasi tersebut.

Pada umumnya tujuan akuntansi adalah menyajikan informasi ekonomi dari satu kesatuan ekonomi kepada pihak-pihak yang berkepentingan. Sedangkan hasil dari proses akuntansi yang berbentuk laporan keuangan yang diharapkan dapat membantu bagi pemakai informasi keuangan.

Dapat ditarik kesimpulan tentang pengertian akuntansi yaitu suatu disiplin ilmu yang menyediakan informasi yang diperlukan perusahaan dalam melaksanakan kegiatannya, secara efisien dan mengevaluasi kegiatan-kegiatan suatu organisasi untuk menghasilkan suatu laporan keuangan yang akan menjadi dasar manajemen dalam pengambilan keputusan.

\section{Piutang}

Hubungan antara piutang dagang dan penjualan kredit di mana piutang dagang khususnya digunakan untuk tagihan yang timbul karena penjualan barang atau jasa secara kredit, di mana pembeli tidak memberikan surat janji tertulis formal. Jadi secara real piutang dagang timbul karena adanya transaksi penjualan kredit, oleh karena itu besar kecilnya penjualan kredit akan berpengaruh langsung terhadap jumlah piutang dagang.

Piutang merupakan harta perusahaan atau koperasi yang timbul karena terjadinya transaksi penjualan secara kredit atas barang dan jasa yang dihasilkan oleh perusahaan.

Dan menurut Kieso, Weygandt, Warfield yang diterjemahkan oleh Herman Wibowo (2002 : 386), piutang diklasifikasikan untuk tujuan laporan keuangan yaitu sebagai berikut: 
1. Piutang Lancar (Jangka Pendek)

2. Piutang Tak Lancar (Jangka Panjang)

\section{Akuntansi Piutang tak tertagih}

Dalam penjualan secara kredit, Penerimaan dan keuntungan akan meningkat, tetapi kerugian yang dialami perusahaan akan meningkat pula karena meningkatnya jumlah piutang yang tidak tertagih. Kerugian ini biasanya kita sebut beban piutang tak tertagih. Besar dari beban piutang tak tertagih bervariasi antar perusahaan. Untuk perusahaan yang melakukan penjualan secara kredit, beban piutang tak tertagih merupakan beban yang memang timbul karena kegiatan bisnis perusahaan. Sebagai beban usaha, tentunya beban piutang tak tertagih harus diketahui jumlahnya. Untuk itu, dalam pengukuran jumlah piutang tak tertagih dikenal dua metode yakni metode cadangan kerugian piutang dan metode penghapusan langsung.

\section{Metode Cadangan Kerugian Piutang}

Dalam metode cadangan setiap akhir periode dilakukan penaksiran jumlah kerugian piutang yang akan dibebankan ke periode yang bersangkutan. Ada tiga metode yang dapat digunakan untuk menentukan jumlah kerugian piutang, yaitu:

1. Menentukan jumlah kerugian piutang berdasarkan jumlah penjualan (pendekatan labarugi). .

2. Menentukan jumlah kerugian piutang berdasarkan saldo piutang (pendekatan neraca).

3. Menentukan jumlah kerugian piutang berdasarkan analisis umur piutang.

\section{Metode Penghapusan Langsung.}

Metode ini biasanya digunakan dalam perusahaan-perusahaan kecil atau perusahaan yang tidak dapat menaksir kerugian piutang dengan tepat. Pada akhir periode tidak ada taksiran kerugian piutang yang dibebankan, tetapi kerugian piutang baru diakui pada waktu diketahui ada piutang yang tidak dapat ditagih. Bila jelas-jelas diketahui adanya piutang yang tidak dapat ditagih, maka piutang tersebut dihapuskan dan dibebankan pada rekening kerugian piutang. Penerimaan dari piutang yang sudah dihapus akan dikreditkan ke rekening kerugian piutang bila buku-buku belum ditutup. Tetapi bila penerimaan piutang yang sudah dihapus itu terjadi sesudah buku-buku ditutup maka akan dikreditkan ke rekening penerimaan piutang yang sudah dihapus.

\section{Umur Piutang}

Suatu bentuk laporan guna mengetahui posisi piutang dengan melakukan pengelompokan piutang pada periode tertentu, dengan pengelompokan tersebut manajemen perusahaan dapat mengetahui posisi piutang sehingga dapat mengambil kebijakan keuangan yang tepat. Dalam buku berjudul "Akuntansi suatu pengantar" umur piutang adalah "Jangka waktu sejak dicatatnya transaksi penjualan sampai dengan saat dibuatnya daftar piutang. "(Soemarso, 2005 : 346).

\section{Perusahaan Manufaktur}

Perusahaan adalah suatu organisasi dimana sumber daya (input) dasar seperti bahan dan tenaga kerja dikelola serta diproses untuk menghasilkan barang atau jasa (output) kepada pelanggan. Hampir di semua perusahaan mempunyai tujuan yang sama, yaitu 
memaksimalkan laba. Jenis perusahaan dibedakan menjadi tiga, yaitu: perusahaan manufaktur, perusahaan dagang, dan perusahaan jasa. Sedangkan bentuk dari perusahaan itu sendiri dibedakan menjadi: perusahaan perseorangan dan persekutuan (perseroan).

Perusahaan manufaktur adalah perusahaan yang kegiatan mengolah bahan baku menjadi barang jadi dan kemudian menjual bahan jadi tersebut. Manufaktur secara luas adalah proses merubah bahan baku menjadi produk yang meliputi perancangan produk, pemilihan material, tahap-tahap proses di mana produk tersebut dibuat. Manufaktur secara umum adalah suatu aktifitas yang kompleks yang melibatkan barbagai variasi sumberdaya dan aktifitas perancangan produk.

\section{Akuntansi Perusahaan Manufaktur}

Menjalankan perusahaan yang telah ada khususnya perusahaan manufaktur terdapat perputaran dalam pengelolaan keuangan. Tanpa pengelolaan keuangan maka laba perusahaan akan tidak berjalan dengan sukses. Bisnis yang keuangannya tidak dikelola dengan baik akan mengalami kegagalan. Untuk menghasilkan laba dan pengelolaan keuangan yang optimal, tiap masing-masing perusahaan harus bekerja seefektif dan seefesien mungkin dalam operasional perusahaan agar laba ini menghasilkan kas yang cukup untuk membayar semua kewajiban yang jatuh tempo.

Akuntansi dikembangkan untuk mengidentifikasi dan mencatat informasi keuangan suatu bisnis. Akuntansi memberikan informasi mengenai aktiva, utang, modal, penghasilan dan biaya suatu perusahaan (unit bisnis). Suatu akuntansi memungkinkan disusunnya laporan keuangan, yaitu neraca dan laporan laba rugi, serta laporan dan analisis lainnya.

\section{METODOLOGI PENELITIAN}

\section{Desain Penelitian}

Dalam penelitian ini menggunakan desain penelitian yang berupa penelitian deskriptif. Secara sistematis, dan akurat mengenai fakta-fakta dan sifat-sifat dari objek penelitian.

\begin{tabular}{lcc}
\multicolumn{3}{c}{ Variabel dan Skala Pengukuran } \\
Skala pengukuran piutang berdasarkan umur piutang: \\
Umur Piutang & Bobot & Nilai \\
1-30 hari & $10 \%$ & Diberikan score 1 \\
31-60 hari & $10-25 \%$ & Diberikan score 2 \\
61-90 hari & $25-40 \%$ & Diberikan score 3 \\
91-181 hari & $40-55 \%$ & Diberikan score 4 \\
181-365 hari & $>55 \%$ & Diberikan score 5 \\
$>1$ tahun & &
\end{tabular}

\section{Metode Pengumpulan Data}

Data-data yang terkumpul dalam penelitian ini diperoleh dengan melakukan penelitian lapangan (Field Research) yaitu penelitian yang dilakukan dengan mengadakan tinjauan langsung pada perusahaan yang menjadi objek penelitian, dengan cara:

1. Observasi yaitu melakukan kunjungan secara langsung pada perusahaan sebagai objek penelitian untuk mendapatkan keterangan yang diperlukan. 
2. Wawancara yaitu dengan mengadakan tanya jawab langsung dengan pimpinan perusahaan mengenai data yang ada sangkut pautnya dengan masalah yang akan dibahas.

3. Membagikan kuesioner dengan menjelaskan terlebih dahulu maksud pertanyaan secara rinci agar memudahkan pihak perusahaan mengisi kuesioner tersebut.

\section{Jenis Data}

Dalam penelitian ini, jenis data yang digunakan yaitu berupa data kualitatif dan kuantitatif. Data kuantitatif merupakan data dalam bentuk angka-angka yang secara langsung diperoleh dari objek penelitian. Sedangkan data kualitatif yaitu merupakan serangkaian informasi yang di dapat dari hasil penelitian berupa fakta-fakta verbal atau keterangan saja.

\section{Populasi dan sampel}

Populasi dalam penelitian ini adalah perusahaan manufaktur. Sampel yang digunakan adalah sampel random. Perusahaan-perusahaan manufaktur tersebut melakukan penjualan secara kredit. Oleh karena itu, sampel yang tersebut dianggap paling representatif untuk dijadikan sampel dalam penelitian ini, karena dengan melakukan penjualan secara kredit akan mengakibatkan kemungkinan timbulnya piutang tak tertagih.

\section{Metode Analisis Data}

Penelitian ini merupakan penelitian di mana dalam menganalisis data penelitian akan menggunakan metode analisis statistik deskriptif. Menurut Nata Wirawan (2002:3) Statistik Deskriptif yaitu statistik yang tingkat pekerjaannya mencakup cara pengumpulan, menyusun, mengolah dan menganalisis data angka, agar dapat memberikan gambaran yang teratur, ringkas dan jelas, mengenai keadaan tertentu sehingga dapat ditarik kesimpulan. Penelitian ini menggunakan wawancara dan kuisioner sebagai media pengumpulan data. Dalam penyusunan kuesioner terdiri pertanyaan berbentuk pilihan ganda yaitu 18 pertanyaan dengan 5 pilihan jawaban dalam bentuk persentase yaitu:

$$
\text { (a) }<10 \% \text {, (b) } 10-25 \% \text {, (c) } 25-40 \% \text {, (d) 40-55\%, (e) > } 55 \% \text {. }
$$

Dalam pengolahan data, disajikan sesuai dengan kelompok pertanyaan khusus yang ada dalam kuisioner mengenai persentase piutang tak tertagih, piutang tertagih, jumlah piutang yang beredar dan tingkat keamanan piutang. Untuk setiap kelompok pertanyaan mengenai piutang yang tertagih, jumlah piutang yang beredar dan tingkat keamanan piutang, masing-masing terdapat 6 pertanyaan, jadi total pertanyaan yaitu 18 pertanyaan.

Kemudian dilakukan perhitungan total score dari masing-masing pertanyaan yang terdiri dari 30 jawaban dari objek penelitian. Jawaban dari responden kemudian diberikan bobot sesuai skala yaitu 1 sampai 5:

1. Nilai $1=<10 \%$

2. Nilai $2=10-25 \%$

3. Nilai $3=25-40 \%$

4. Nilai $4=40-55 \%$

5. Nilai $5=>55 \%$

Setelah itu dibuat skala interval penilaian berdasarkan total score untuk mengetahui rata-rata persentase dari setiap umur piutang. Untuk mengolah data hasil penelitian, 
digunakan skala interval karena data hasil penelitian tidak bisa dijumlahkan secara langsung. Interval penilaian dibagi menjadi 5 kelas data berdasarkan banyaknya pilihan jawaban pada pertanyaan pilihan ganda. Panjang interval diperoleh dengan membagi angka/ total score maksimum dengan banyaknya kelas data. Untuk memperjelas hasil penelitian, maka hasil perhitungan akan di sajikan dalam bentuk diagram batang.

Untuk pengolahan data tentang persentase piutang tak tertagih berdasarkan umur piutang, karena data hasil penelitian bisa langsung dijumlahkan, maka digunakan rumus untuk menghitung rata-rata yaitu:

Rata-rata penetapan persentase piutang tak tertagih berdasarkan umur piutang pada Perusahaan Manufaktur.

$\begin{array}{ll} & =\quad \frac{\text { Jumlah Persentase Piutang Tak Tertagih Keseluruhan }}{\text { Banyaknya Objek Penelitian }} \\ & \mathrm{X} \quad=\quad \sum_{i=1} \frac{\mathrm{xi}}{\mathrm{n}} \\ \mathrm{X} \quad & =\text { Rata-rata penetapan persentase piutang tak tertagih } \\ \mathrm{N} & \text { = Jumlah objek penelitian } \\ \mathrm{Xi} \quad & \text { = Jumlah persentase piutang tak tertagih keseluruhan }\end{array}$

\section{HASIL DAN PEMBAHASAN}

\section{Analisis Hasil}

Dari kuesioner yang telah diisi, diperoleh data mengenai persentase piutang tak tertagih, persentase piutang yang biasanya tertagih, persentase jumlah piutang yang beredar menurut umur piutang, dan tingkat keamanan piutang menurut masing-masing manajemen perusahaan manufaktur yang di analisis.

Semua data yang diperoleh dari objek penelitian mengenai persentase piutang yang biasanya tertagih, persentase jumlah piutang yang beredar menurut umur piutang, dan tingkat keamanan piutang menurut masing-masing manajemen perusahaan, akan ditabulasikan ke dalam tabel sesuai klasifikasi pertanyaan, dan dilakukan perhitungan total score yang kemudian akan dinilai berdasarkan skala interval.

Semua data yang diperoleh dari objek penelitian mengenai piutang yang biasanya tertagih, piutang yang beredar menurut umur piutang, dan tingkat keamanan piutang menurut manajemen perusahaan akan ditabulasikan ke dalam tabel sesuai klasifikasi pertanyaan, dan dilakukan perhitungan total score yang kemudian akan dinilai berdasarkan skala interval.

Data tersebut dibuat tabel berdasarkan masing-masing tiap perusahaan.

Dari tabel 4.31- 4.34.

Keterangan : $\quad 1=$ Nilai untuk persentase $<10 \%$

$2=$ Nilai untuk persentase $10-25 \%$

$3=$ Nilai untuk persentase $25-40 \%$

$4=$ Nilai untuk persentase $40-55 \%$

$5=$ Nilai untuk persentase $>55 \%$ 
Tabel 1

Perhitungan Total Score Piutang yang biasanya Tertagih Pada Perusahaan Manufaktur

\begin{tabular}{|c|c|c|c|c|c|c|c|}
\hline \multirow{2}{*}{ No } & \multirow{2}{*}{ Nama Perusahaan Manufaktur } & \multicolumn{6}{|c|}{ Umur piutang } \\
\hline & & $\begin{array}{l}1-30 \\
\text { hari }\end{array}$ & $\begin{array}{l}31- \\
60 \\
\text { hari } \\
\end{array}$ & $\begin{array}{l}61- \\
90 \\
\text { hari }\end{array}$ & $\begin{array}{l}\text { 91- } \\
180 \\
\text { hari }\end{array}$ & $\begin{array}{l}181- \\
365 \\
\text { hari }\end{array}$ & $\begin{array}{l}>1 \\
\text { tahun }\end{array}$ \\
\hline 1 & PT. Aditya Srijaya Perkasa & 5 & 4 & 3 & 2 & 2 & 1 \\
\hline 2 & PT. Alkausar Putra Indonesia & 5 & 5 & 5 & 5 & 5 & 1 \\
\hline 3 & PT. Anugrah Argon Medica & 5 & 3 & 4 & 5 & 5 & 5 \\
\hline 4 & PT. Dafa Furniture & 5 & 4 & 2 & 2 & 1 & 1 \\
\hline 5 & PT. Darindo Zelva Mulya & 5 & 4 & 1 & 1 & 1 & 1 \\
\hline 6 & PT. Dhap Indonesia & 4 & 5 & 3 & 2 & 1 & 1 \\
\hline 7 & CV. Dinamis Mandiri Jaya & 5 & 4 & 3 & 2 & 1 & 1 \\
\hline 8 & PT. Diwantama & 1 & 2 & 3 & 4 & 2 & 3 \\
\hline 9 & PT. Fajar Lestari Sejati & 3 & 4 & 5 & 5 & 5 & 5 \\
\hline 10 & PT. Graha Mitra Arsindo & 5 & 5 & 4 & 3 & 1 & 1 \\
\hline 11 & PT. Hanang Gema Instrument & 5 & 5 & 4 & 4 & 3 & 2 \\
\hline 12 & PT. Heavenly Nutrition Indonesia & 5 & 4 & 3 & 2 & 1 & 1 \\
\hline 13 & PT. Japfa Comfeed Indonesia, tbk & 5 & 4 & 2 & 2 & 1 & 1 \\
\hline 14 & PT. Kimia Farma, tbk & 5 & 5 & 5 & 5 & 1 & 1 \\
\hline 15 & PT. Komugi Panen Anugrah & 4 & 4 & 3 & 1 & 1 & 1 \\
\hline 16 & PT. Malindo Feedmil, tbk & 5 & 5 & 5 & 5 & 5 & 2 \\
\hline 17 & PT. Merapi & 5 & 2 & 1 & 2 & 2 & 1 \\
\hline 18 & PT. Novell Pharmaceutical Laboratories & 1 & 2 & 3 & 4 & 4 & 5 \\
\hline 19 & PT. Parazelsus & 5 & 5 & 4 & 1 & 1 & 1 \\
\hline 20 & PT. Performance & 3 & 4 & 5 & 5 & 5 & 5 \\
\hline 21 & PT. Prima Furniture & 5 & 4 & 2 & 2 & 1 & 1 \\
\hline 22 & PT. Rajawali Medika & 5 & 4 & 3 & 2 & 2 & 1 \\
\hline 23 & PT. Rejeki Utama & 5 & 4 & 3 & 2 & 2 & 1 \\
\hline 24 & PT. Sarana Artha Grahawisesa & 4 & 3 & 2 & 1 & 1 & 1 \\
\hline 25 & PT. Sekarguna & 5 & 2 & 2 & 1 & 1 & 1 \\
\hline 26 & PT. Social House & 5 & 4 & 3 & 2 & 2 & 1 \\
\hline 27 & PT. Swanindo Sakti & 5 & 5 & 5 & 5 & 5 & 5 \\
\hline 28 & PT. Swastika Anugraha Mahardika & 4 & 5 & 4 & 2 & 1 & 1 \\
\hline
\end{tabular}




\begin{tabular}{|l|l|l|l|l|l|l|l|}
\hline 29 & PT. Trinika Energi Utama & 5 & 4 & 4 & 3 & 1 & 1 \\
\hline 30 & PT. Varia Baru & 5 & 4 & 3 & 2 & 2 & 1 \\
\hline \multicolumn{2}{|l}{ Total Score } & $\mathbf{1 3 4}$ & $\mathbf{1 1 9}$ & $\mathbf{9 9}$ & $\mathbf{8 4}$ & $\mathbf{6 6}$ & $\mathbf{5 4}$ \\
\hline
\end{tabular}

Sumber : Data yang Diolah : 2013

Tabel 2

Perhitungan Total Score Piutang yang beredar

Menurut Umur Piutang

\begin{tabular}{|c|c|c|c|c|c|c|c|}
\hline \multirow{2}{*}{ No } & \multirow{2}{*}{ Nama Perusahaan Manufaktur } & \multicolumn{6}{|c|}{ Umur piutang } \\
\hline & & $\begin{array}{l}1-30 \\
\text { hari }\end{array}$ & $\begin{array}{l}31- \\
60 \\
\text { hari }\end{array}$ & $\begin{array}{l}61- \\
90 \\
\text { hari }\end{array}$ & $\begin{array}{l}91- \\
180 \\
\text { hari }\end{array}$ & $\begin{array}{l}\text { 181- } \\
365 \\
\text { hari }\end{array}$ & $\begin{array}{l}>1 \\
\text { tahun }\end{array}$ \\
\hline 1 & PT. Aditya Srijaya Perkasa & 3 & 2 & 2 & 4 & 4 & 4 \\
\hline 2 & PT. Alkausar Putra Indonesia & 5 & 5 & 4 & 1 & 2 & 1 \\
\hline 3 & PT. Anugrah Argon Medica & 4 & 4 & 2 & 3 & 3 & 3 \\
\hline 4 & PT. Dafa Furniture & 5 & 4 & 2 & 1 & 1 & 1 \\
\hline 5 & PT. Darindo Zelva Mulya & 5 & 3 & 1 & 1 & 2 & 1 \\
\hline 6 & PT. Dhap Indonesia & 5 & 5 & 3 & 2 & 2 & 2 \\
\hline 7 & CV. Dinamis Mandiri Jaya & 5 & 4 & 4 & 1 & 1 & 1 \\
\hline 8 & PT. Diwantama & 1 & 2 & 3 & 4 & 2 & 3 \\
\hline 9 & PT. Fajar Lestari Sejati & 3 & 2 & 4 & 2 & 4 & 2 \\
\hline 10 & PT. Graha Mitra Arsindo & 5 & 5 & 4 & 4 & 1 & 1 \\
\hline 11 & PT. Hanang Gema Instrument & 5 & 4 & 3 & 2 & 2 & 1 \\
\hline 12 & PT. Heavenly Nutrition Indonesia & 5 & 4 & 3 & 2 & 1 & 1 \\
\hline 13 & PT. Japfa Comfeed Indonesia, tbk & 5 & 4 & 2 & 1 & 1 & 1 \\
\hline 14 & PT. Kimia Farma, tbk & 5 & 2 & 1 & 1 & 1 & 1 \\
\hline 15 & PT. Komugi Panen Anugrah & 5 & 3 & 4 & 2 & 3 & 1 \\
\hline 16 & PT. Malindo Feedmil, tbk & 5 & 2 & 2 & 1 & 1 & 1 \\
\hline 17 & PT. Merapi & 5 & 3 & 2 & 1 & 3 & 1 \\
\hline 18 & PT. Novell Pharmaceutical Laboratories & 1 & 2 & 3 & 4 & 4 & 4 \\
\hline 19 & PT. Parazelsus & 5 & 5 & 4 & 1 & 1 & 1 \\
\hline 20 & PT. Performance & 3 & 3 & 4 & 4 & 5 & 5 \\
\hline 21 & PT. Prima Furniture & 5 & 4 & 2 & 1 & 1 & 1 \\
\hline 22 & PT. Rajawali Medika & 5 & 5 & 3 & 2 & 1 & 1 \\
\hline 23 & PT. Rejeki Utama & 3 & 2 & 2 & 3 & 4 & 4 \\
\hline 24 & PT. Sarana Artha Grahawisesa & 5 & 5 & 4 & 3 & 2 & 1 \\
\hline 25 & PT. Sekarguna & 5 & 2 & 2 & 1 & 1 & 1 \\
\hline
\end{tabular}




\begin{tabular}{|l|l|l|l|l|l|l|l|}
\hline 26 & PT. Social House & 5 & 4 & 3 & 1 & 1 & 1 \\
\hline 27 & PT. Swanindo Sakti & 5 & 2 & 1 & 1 & 1 & 1 \\
\hline 28 & PT. Swastika Anugraha Mahardika & 3 & 4 & 4 & 3 & 1 & 1 \\
\hline 29 & PT. Trinika Energi Utama & 5 & 4 & 2 & 2 & 1 & 1 \\
\hline 30 & PT. Varia Baru & 3 & 2 & 2 & 4 & 4 & 4 \\
\hline Total Score & $\mathbf{1 2 9}$ & $\mathbf{1 0 2}$ & $\mathbf{8 2}$ & $\mathbf{6 3}$ & $\mathbf{6 1}$ & $\mathbf{5 2}$ \\
\hline
\end{tabular}

Sumber : Data yang Diolah : 2013

Tabel 3

Perhitungan Tingkat Keamanan Piutang menurut Manajemen Perusahaan

\begin{tabular}{|c|c|c|c|c|c|c|c|}
\hline \multirow{2}{*}{ No } & \multirow[b]{2}{*}{ Nama Perusahaan Manufaktur } & \multicolumn{6}{|c|}{ Umur Piutang } \\
\hline & & $\begin{array}{l}1-30 \\
\text { hari }\end{array}$ & $\begin{array}{l}31- \\
60 \\
\text { hari }\end{array}$ & $\begin{array}{l}61- \\
90 \\
\text { hari } \\
\end{array}$ & $\begin{array}{l}91- \\
180 \\
\text { hari }\end{array}$ & $\begin{array}{l}\text { 181- } \\
365 \\
\text { hari }\end{array}$ & $\begin{array}{l}>1 \\
\text { tahun }\end{array}$ \\
\hline 1 & PT. Aditya Srijaya Perkasa & 5 & 4 & 3 & 2 & 2 & 1 \\
\hline 2 & PT. Alkausar Putra Indonesia & 5 & 4 & 3 & 3 & 2 & 1 \\
\hline 3 & PT. Anugrah Argon Medica & 4 & 4 & 3 & 3 & 2 & 2 \\
\hline 4 & PT. Dafa Furniture & 5 & 4 & 4 & 2 & 2 & 1 \\
\hline 5 & PT. Darindo Zelva Mulya & 5 & 4 & 3 & 2 & 1 & 0 \\
\hline 6 & PT. Dhap Indonesia & 5 & 4 & 4 & 2 & 2 & 1 \\
\hline 7 & CV. Dinamis Mandiri Jaya & 5 & 4 & 3 & 2 & 2 & 1 \\
\hline 8 & PT. Diwantama & 4 & 3 & 3 & 2 & 1 & 1 \\
\hline 9 & PT. Fajar Lestari Sejati & 3 & 2 & 1 & 1 & 1 & 1 \\
\hline 10 & PT. Graha Mitra Arsindo & 5 & 5 & 4 & 4 & 5 & 2 \\
\hline 11 & PT. Hanang Gema Instrument & 5 & 4 & 3 & 2 & 2 & 1 \\
\hline 12 & PT. Heavenly Nutrition Indonesia & 5 & 4 & 3 & 1 & 1 & 1 \\
\hline 13 & PT. Japfa Comfeed Indonesia, tbk & 5 & 4 & 3 & 2 & 1 & 1 \\
\hline 14 & PT. Kimia Farma, tbk & 4 & 4 & 3 & 3 & 2 & 1 \\
\hline 15 & PT. Komugi Panen Anugrah & 4 & 4 & 3 & 1 & 1 & 0 \\
\hline 16 & PT. Malindo Feedmil, tbk & 5 & 4 & 3 & 3 & 2 & 0 \\
\hline 17 & PT. Merapi & 5 & 4 & 3 & 2 & 1 & 1 \\
\hline 18 & PT. Novell Pharmaceutical Laboratories & 4 & 4 & 3 & 4 & 4 & 2 \\
\hline 19 & PT. Parazelsus & 5 & 4 & 4 & 2 & 2 & 1 \\
\hline 20 & PT. Performance & 5 & 4 & 3 & 2 & 1 & 1 \\
\hline 21 & PT. Prima Furniture & 5 & 4 & 4 & 2 & 2 & 1 \\
\hline 22 & PT. Rajawali Medika & 5 & 4 & 3 & 3 & 1 & 0 \\
\hline 23 & PT. Rejeki Utama & 5 & 4 & 3 & 2 & 2 & 2 \\
\hline 24 & PT. Sarana Artha Grahawisesa & 5 & 4 & 3 & 2 & 1 & 0 \\
\hline 25 & PT. Sekarguna & 5 & 4 & 3 & 2 & 1 & 0 \\
\hline 26 & PT. Social House & 5 & 4 & 3 & 2 & 1 & 0 \\
\hline 27 & PT. Swanindo Sakti & 5 & 4 & 3 & 3 & 2 & 0 \\
\hline
\end{tabular}




\begin{tabular}{|l|l|l|l|l|l|l|l|}
28 & PT. Swastika Anugraha Mahardika & 5 & 4 & 5 & 2 & 1 & 1 \\
\hline 29 & PT. Trinika Energi Utama & 5 & 2 & 1 & 1 & 1 & 0 \\
\hline 30 & PT. Varia Baru & 5 & 4 & 3 & 2 & 2 & 1 \\
\hline Total Score & $\mathbf{1 4 3}$ & $\mathbf{1 1 6}$ & $\mathbf{9 3}$ & $\mathbf{6 6}$ & $\mathbf{5 1}$ & $\mathbf{2 5}$ \\
\hline
\end{tabular}

Sumber: Data yang diolah : 2013

\section{Pembahasan}

Metode analisa piutang berdasarkan umur piutang banyak digunakan karena merupakan salah satu metode yang dianggap paling tepat. Hal ini terutama dalam melakukan analisa piutang tak tertagih dengan mengelompokkan piutang berdasarkan umur, dianggap paling tepat untuk menggambarkan kerugian yang nantinya diakibatkan oleh piutang yang mungkin tidak tertagih.

\section{Penetapan Persentase Piutang tak Tertagih pada Perusahaan Manufaktur}

Tabel 4

\section{Persentase Piutang tak tertagih}

\begin{tabular}{|c|c|c|c|c|c|c|c|}
\hline \multirow[t]{2}{*}{ No } & \multirow[b]{2}{*}{ Nama Perusahaan Manufaktur } & \multicolumn{6}{|c|}{ Umur Piutang } \\
\hline & & $\begin{array}{l}30 \\
\text { hari }\end{array}$ & $\begin{array}{l}\text { 31-60 } \\
\text { hari }\end{array}$ & $\begin{array}{l}\text { 61-90 } \\
\text { hari }\end{array}$ & $\begin{array}{l}91-180 \\
\text { hari }\end{array}$ & $\begin{array}{l}181- \\
365 \\
\text { hari }\end{array}$ & $\begin{array}{l}>1 \\
\text { tahun }\end{array}$ \\
\hline 1 & PT. Aditya Srijaya Perkasa & $0 \%$ & $0,5 \%$ & $10 \%$ & $20 \%$ & $30 \%$ & $40 \%$ \\
\hline 2 & PT. Alkausar Putra Indonesia & $0,5 \%$ & $10 \%$ & $20 \%$ & $30 \%$ & $50 \%$ & $50 \%$ \\
\hline 3 & PT. Anugrah Argon Medica & $100 \%$ & $55 \%$ & $80 \%$ & $70 \%$ & $40 \%$ & $55 \%$ \\
\hline 4 & PT. Dafa Furniture & $20 \%$ & $30 \%$ & $40 \%$ & $30 \%$ & $20 \%$ & $10 \%$ \\
\hline 5 & PT. Darindo Zelva Mulya & $10 \%$ & $20 \%$ & $30 \%$ & $70 \%$ & $80 \%$ & $90 \%$ \\
\hline 6 & PT. Dhap Indonesia & $0 \%$ & $0,5 \%$ & $10 \%$ & $20 \%$ & $30 \%$ & $25 \%$ \\
\hline 7 & CV. Dinamis Mandiri Jaya & $0,5 \%$ & $10 \%$ & $20 \%$ & $30 \%$ & $45 \%$ & $40 \%$ \\
\hline 8 & PT. Diwantama & $25 \%$ & $10 \%$ & $40 \%$ & $25 \%$ & $10 \%$ & $10 \%$ \\
\hline 9 & PT. Fajar Lestari Sejati & $20 \%$ & $20 \%$ & $30 \%$ & $50 \%$ & $70 \%$ & $90 \%$ \\
\hline 10 & PT. Graha Mitra Arsindo & $0,5 \%$ & $0,5 \%$ & $15 \%$ & $10 \%$ & $10 \%$ & $20 \%$ \\
\hline 11 & PT. Hanang Gema Instrument & $0,5 \%$ & $10 \%$ & $15 \%$ & $20 \%$ & $40 \%$ & $50 \%$ \\
\hline 12 & PT. Heavenly Nutrition Indonesia & $10 \%$ & $15 \%$ & $20 \%$ & $30 \%$ & $40 \%$ & $55 \%$ \\
\hline 13 & PT. Japfa Comfeed Indonesia, tbk & $0 \%$ & $0,5 \%$ & $0,5 \%$ & $10 \%$ & $15 \%$ & $10 \%$ \\
\hline 14 & PT. Kimia Farma, tbk & $0 \%$ & $0,2 \%$ & $0,3 \%$ & $0,5 \%$ & $20 \%$ & $70 \%$ \\
\hline 15 & PT. Komugi Panen Anugrah & $20 \%$ & $30 \%$ & $40 \%$ & $60 \%$ & $70 \%$ & $80 \%$ \\
\hline 16 & PT. Malindo Feedmil, tbk & $0 \%$ & $10 \%$ & $30 \%$ & $50 \%$ & $50 \%$ & $100 \%$ \\
\hline 17 & PT. Merapi & $0 \%$ & $0,5 \%$ & $10 \%$ & $10 \%$ & $25 \%$ & $40 \%$ \\
\hline 18 & $\begin{array}{l}\text { PT. Novell } \\
\text { Laboratories }\end{array}$ & $0 \%$ & $25 \%$ & $35 \%$ & $60 \%$ & $65 \%$ & $100 \%$ \\
\hline 19 & PT. Parazelsus & $0 \%$ & $0,5 \%$ & $10 \%$ & $15 \%$ & $20 \%$ & $80 \%$ \\
\hline 20 & PT. Performance & $0 \%$ & $0 \%$ & $10 \%$ & $25 \%$ & $75 \%$ & $100 \%$ \\
\hline 21 & PT. Prima Furniture & $10 \%$ & $20 \%$ & $60 \%$ & $80 \%$ & $80 \%$ & $90 \%$ \\
\hline
\end{tabular}




\begin{tabular}{|l|l|l|l|l|l|l|l|}
22 & PT. Rajawali Medika & $10 \%$ & $10 \%$ & $10 \%$ & $10 \%$ & $0,5 \%$ & $100 \%$ \\
\hline 23 & PT. Rejeki Utama & $20 \%$ & $30 \%$ & $40 \%$ & $50 \%$ & $60 \%$ & $80 \%$ \\
\hline 24 & PT. Sarana Artha Grahawisesa & $0,5 \%$ & $10 \%$ & $25 \%$ & $40 \%$ & $40 \%$ & $60 \%$ \\
\hline 25 & PT. Sekarguna & $0 \%$ & $0 \%$ & $0 \%$ & $15 \%$ & $10 \%$ & $80 \%$ \\
\hline 26 & PT. Social House & $20 \%$ & $40 \%$ & $70 \%$ & $80 \%$ & $90 \%$ & $90 \%$ \\
\hline 27 & PT. Swanindo Sakti & $0 \%$ & $0 \%$ & $0 \%$ & $0 \%$ & $50 \%$ & $100 \%$ \\
\hline 28 & PT. Swastika Anugraha Mahardika & $0 \%$ & $15 \%$ & $30 \%$ & $30 \%$ & $50 \%$ & $100 \%$ \\
\hline 29 & PT. Trinika Energi Utama & $0 \%$ & $0 \%$ & $10 \%$ & $25 \%$ & $75 \%$ & $100 \%$ \\
\hline 30 & PT. Varia Baru & $10 \%$ & $40 \%$ & $60 \%$ & $80 \%$ & $100 \%$ & $100 \%$ \\
\hline Total Score & $\mathbf{2 7 5 \%}$ & $\mathbf{4 1 0 \%}$ & $\mathbf{7 7 0 \%}$ & $\mathbf{1 0 4 5 \%}$ & $\mathbf{1 3 6 0 \%}$ & $\mathbf{2 0 1 5 \%}$ \\
\hline
\end{tabular}

Sumber: Data Olahan : 2013

Dari tabel diatas dapat dilihat penetapan persentase piutang tak tertagih yang ditetapkan oleh perusahaan manufaktur di Jakarta. Untuk mengetahui rata-rata persentase piutang tak tertagih menurut analisa umur piutang pada perusahaan manufaktur, maka dilakukan perhitungan sebagai berikut:

1). 1-30 hari, $X=\frac{2.75 \times 100 \%}{30}$

$$
=9.16 \%
$$

2). 31-60 hari, $X=\frac{4.10 \times 100 \%}{30}$

$$
=13.66 \%
$$

3). $61-90$ hari, $X=\underline{7.70 \times 100 \%}$

$$
30
$$

$=25.66 \%$

4). $91-180$ hari, $X=\underline{10.45 \times 100 \%}$

$=34.83 \%$

5). $181-365$ hari, $X=\underline{13.60 \times 100 \%}$

$=45.33 \%$

6). $>1$ tahun, $X=\underline{20.15 \times 100 \%}$

$$
\begin{array}{r}
30 \\
=67.16 \%
\end{array}
$$

Menurut perhitungan diatas, rata-rata persentase piutang tak tertagih yang ditetapkan pada perusahaan manufaktur dapat dilihat pada gambar grafik .

\section{Gambar 1}

Grafik Rata-rata Persentase Piutang tak Tertagih berdasarkan Umur Piutang 
pada Perusahaan Manufaktur

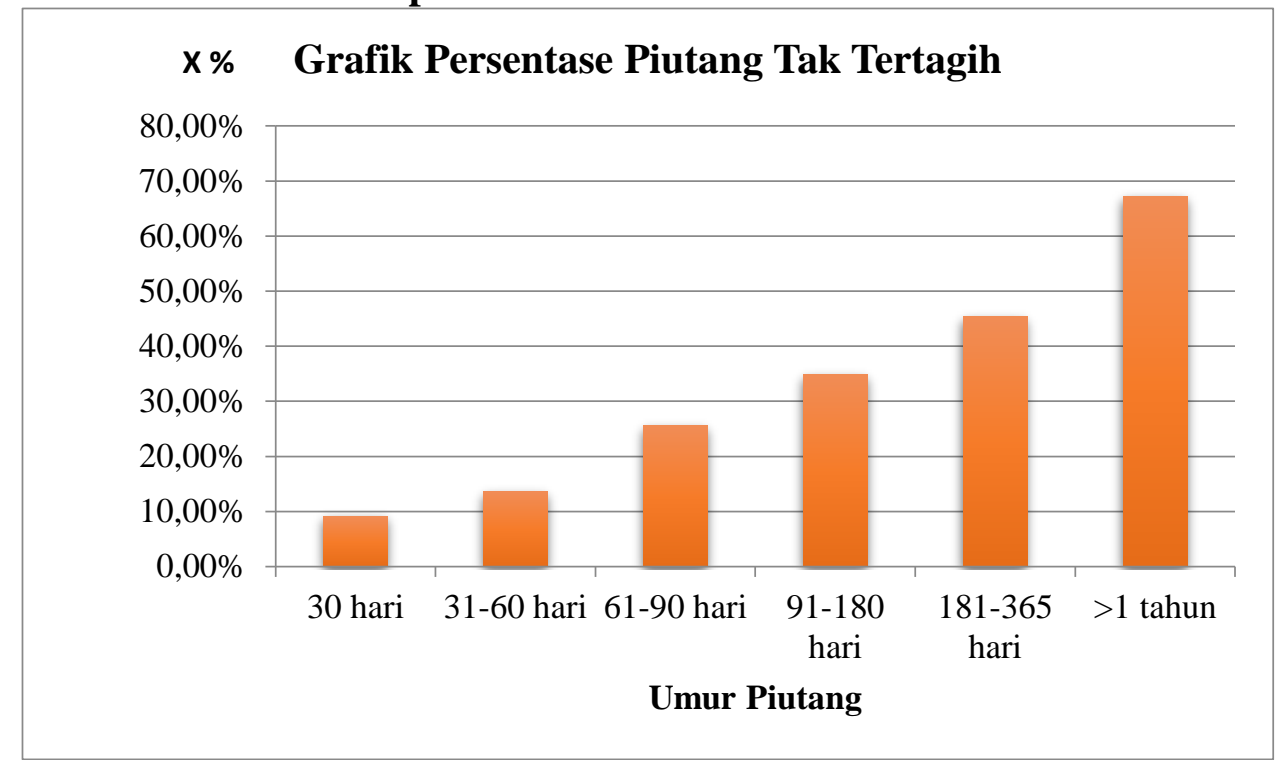

Sumber: Data Olahan : 2013

\section{Penetapan Persentase Piutang yang biasanya Tertagih}

Setelah dilakukan tabulasi data untuk menghitung total score, setiap total score akan dinilai dengan menggunakan skala interval yang ditunjukkan pada tabel 4.9 , sehingga rata-rata persentase piutang yang biasanya tertagih dapat diketahui.

Tabel 5

Penilaian Piutang yang biasanya tertagih

\begin{tabular}{|l|l|}
\hline Interval & Penilaian \\
\hline $1-30$ & $<10 \%$ \\
\hline $31-60$ & $10-25 \%$ \\
\hline $61-90$ & $25-40 \%$ \\
\hline $91-120$ & $40-55 \%$ \\
\hline $121-150$ & $>55 \%$ \\
\hline
\end{tabular}

Sumber : Data yang diolah : 2013

Angka tertinggi pada interval diperoleh dari banyaknya objek penelitian dikalikan dengan bobot tertinggi yaitu $30 \times 5=150$. Sedangkan angka terendah diperoleh dari banyaknya objek penelitian dikalikan dengan bobot terendah yaitu $30 \times 1=30$. Dikalikan dengan banyaknya objek penelitian karena perhitungan akan dilakukan pada setiap umur piutang untuk menghitung rata-rata, dimana setiap pertanyaan memiliki 30 jawaban yaitu dari 30 objek penelitian. Panjang interval diperoleh dari angka maksimum dibagi dengan banyaknya kelas data yaitu $150: 5=30$. Berdasarkan tabel 4.31 , maka persentase dari piutang yang biasanya tertagih dari masing-masing umur piutang yaitu : 30 hari total score 134 berada pada interval 120-150 yaitu >55\%, 31-60 hari total score 119 berada pada interval 90-120 yaitu 40-55\%, 61-90 hari total score 99 berada pada interval 90-120 yaitu 40-55\%, 91-180 hari total score 84 berada pada interval 60-90 yaitu 25-40\%, 181- 
365 hari total score 66 berada pada interval 60-90 yaitu 25-40\%, >1 tahun total score 54 berada pada interval 30-60 yaitu 10-25\%.

\section{Penetapan Persentase Piutang yang beredar Menurut Umur Piutang}

Untuk mengetahui rata-rata persentase piutang yang beredar menurut umur piutang, secara khusus dinilai dengan menggunakan skala interval yang sama dengan piutang yang biasanya tertagih yaitu pada tabel 4.35. Berdasarkan tabel 4.32, maka rata-rata persentase piutang yang beredar menurut umur piutang adalah : 30 hari total score 129 berada pada interval 120-150 yaitu >55\%, 31-60 hari total score 102 berada pada interval 90-120 yaitu 40-55\%, 61-90 hari total score 82 berada pada interval 60-90 yaitu 25-40\%, 91-180 hari total score 63 berada pada interval 60-90 yaitu 25-40\%, 181-365 hari total score 61 berada pada interval 60-90 yaitu 25-40\%, dan >1 tahun total score 52 berada pada interval 30-60 yaitu $10-25 \%$.

\section{Penetapan Persentase Tingkat Keamanan Piutang menurut Manajemen Perusahaan}

Berdasarkan jumlah objek penelitian sebanyak 30 perusahaan manufaktur, score tertinggi dan terendah yaitu 1 dan 150. Maka secara khusus dibuat skala interval untuk melakukan penilaian terhadap tingkat keamanan piutang berdasarkan umur piutang, dengan perhitungan panjang interval yang sama seperti perhitungan interval pada tabel 4.35 .

Tabel 6

Penilaian Tingkat Keamanan Piutang

\begin{tabular}{|l|l|}
\hline Interval & Penilaian \\
\hline $1-30$ & Tidak aman \\
\hline $31-60$ & Kurang aman \\
\hline $61-90$ & Cukup aman \\
\hline $91-120$ & Aman \\
\hline $121-150$ & Paling aman \\
\hline
\end{tabular}

Sumber : Data yang diolah

Dari tabel 4.33 yaitu total score masing-masing umur piutang, maka rata-rata penilaian terhadap keamanan piutang adalah: 30 hari total score 143 berada pada interval 120-150 yaitu >55\%, 31-60 hari total score 116 berada pada interval 90-120 yaitu 4055\%, 61-90 hari total score 93 berada pada interval 90-120 yaitu 40-55\%, 91-180 hari total score 66 berada pada interval 60-90 yaitu 25-40\%, 181-365 hari total score 51 berada pada interval 30-60 yaitu 10-25\%, dan $>1$ tahun total score 25 berada pada interval $1-30$ yaitu $<10 \%$.

Untuk piutang yang berumur 1-3 bulan atau berada dibawah 90 hari masih dikategorikan sebagai piutang yang cukup aman artinya masih belum berpengaruh pada pendapatan perusahaan tersebut, karena rata-rata umur piutang ini bisa ditagih. Namun untuk piutang yang berumur 181-365 hari dan lebih dari 1 tahun, perusahaan menganggap piutang ini sudah berada pada tingkat yang tidak aman yang akan mempengaruhi keuangan dan pendapatan pihak perusahaan.

\section{KESIMPULAN DAN SARAN}




\section{Kesimpulan}

Berdasarkan hasil penelitian yang dilakukan oleh penulis terhadap perusahaan manufaktur, maka dapat disimpulkan bahwa:

1. Dari hasil perhitungan rata-rata persentase piutang tak tertagih menurut umur piutang pada perusahaan manufaktur, maka diketahui bahwa semakin lama umur piutang, maka semakin besar persentase piutang tak tertagih. Piutang yang berumur 1-30 hari rata-ratanya $9.16 \%, 31-60$ hari rata-ratanya $13.66 \%, 61-90$ hari rata-ratanya $25.66 \%$, 91-180 hari rata-ratanya 34.83\%, 181-365 hari rata-ratanya $45.33 \%,>1$ tahun rataratanya $67.16 \%$.

2. Piutang yang biasanya tertagih dalam jumlah besar yaitu piutang yang berumur 1-30 hari dimana rata-rata persentase piutang yang biasanya tertagih yaitu $>55 \%$ sedangkan untuk piutang yang kecil kemungkinannya untuk tertagih adalah piutang yang berumur $>1$ tahun dimana rata-rata persentase piutang yang biasanya tertagih yaitu sebesar $10-25 \%$.

3. Rata-rata piutang yang beredar menurut umur piutang yang paling banyak yaitu piutang yang berumur 1-30 hari yaitu $>55 \%$.

4. Perusahaan Manufaktur mengklasifikasikan piutang yang berumur 181-365 hari dan $>1$ tahun sebagai piutang yang kurang aman dan tidak aman yang sudah tidak tertagih.

\section{Saran}

Piutang merupakan hal yang sangat vital yang mempengaruhi laba perusahaan, oleh karena itu, sebaiknya pihak perusahaan harus semaksimal mungkin menekan timbulnya piutang. Misalnya dengan melaksanakan pengelolaan piutang secara efektif atau memperketat sistem pengawasan terhadap piutang. Sebaiknya perusahaan manufaktur harus lebih teliti dalam pengawasan dan evaluasi kondisi keuangan pelanggan dan melakukan pengawasan secara ketat agar tidak kehilangan kontak dengan pelanggan dan agar tidak ada pelanggan yang melarikan diri yang dapat menyebabkan piutang tak dapat tertagih. Selain itu, pihak perusahaan harus terus melakukan analisa berdasarkan umur piutang terutama dalam menentukan persentase piutang yang tidak tertagih agar dapat mengetahui kondisi piutang terutama jumlah kerugian yang mungkin ditimbulkan oleh piutang tersebut atau biasa disebut cadangan kerugian piutang.

\section{DAFTAR PUSTAKA}

Dunia Firdaus, 2005, Ikhtisar Lengkap Pengantar Akuntansi, edisi kedua, Penerbit Fakultas Ekonomi Universitas Indonesia, Jakarta.

Husnan Pudjiastuti, 2004, Dasar-dasar Manajemen Keuangan, Penerbit UPP AMD YKPN Yogyakarta.

Jusup Haryono, 2002, Dasar-dasar Akuntansi, Edisi 6 Jilid 2, BPFE, Yogyakarta.

Lukas Setia Atmaja, 2008, Teori dan Praktek Manajemen Keuangan, Penerbit CV Andi Offset ( Andi ). 
Soemarso, 2004, Akuntansi Suatu Pengantar, Penerbit Salemba Empat.

Ikatan Akuntan Indonesia, 2004, Standar Akuntansi Keuangan, Salemba Empat.

Drs. Gempur Santoso. 2005, Metodologi Penelitian, Penerbit Prestasi Pustaka Publisher.

M. Natsir, 2005, Metode Penelitian, Penerbit Ghalia.

Christine Y.A Mawitjere, 2006, Analisis Piutang Tak Tertagih Berdasarkan Umur Piutang Pada Hotel Berbintang di Kota Manado: Manado. 
